\title{
Morphological Errors Analysis on Students' Synopsis Writing
}

\author{
Irpan Ali Rahman \\ Universitas Buddhi Dharma, Tangerang, Banten, Indonesia \\ Irpanalirahman@gmail.com
}

\begin{abstract}
The objective of the study is to find out the students' morphological errors in synopsis writing. It aimed to know what the difficulty is faced by the students in their synopsis writing. The methodology of study is a qualitative that focused to analyze the students' synopsis writing errors. The research finding is found that several students have synopsis writing errors in some aspects refer to omission, misordering, misinformation, and addition.
\end{abstract}

Keywords: morphological errors, students' synopsis writing

Citation APA Style: Rahman, I. A. (2019). Morphological Errors Analysis on Students' Synopsis Writing. English Language in Focus (ELIF), 1(2), 81-88.

\section{INTRODUCTION}

W skill is one of the productive skills in mastering the language. Writing is the process of expressing ideas and feeling using a proper language. Many students are still getting difficulty in expressing ideas through good grammar and diction. Errors happen when someone creates improper expression due to memory limitation, fatigue or emotional strain. The speaker is actually able to correct his/her improper expression. When the writer or the speaker creates improper expression due to imperfect competence in the target language then it is called an error.

Synopsis is one of suitable writing material for higher level students because they can share their ideas, opinion, and response also critics through synopsis writing for film or drama. Synopsis is a brief summary or overview. ynopsis is a short description of your screenplay. It consists of a plot summary of the screenplay on a sheet of paper and usually contains no more than 400 words. It highlights the main characters and what they go through during the story.

A good synopsis will focus a lot of attention to conflict and resolution. Kennedy, Kennedy, \& Muth (2011) stated that a synopsis can help the reader to recall and to review the story's specifics. Film synopsis must be original in plot and focus on the most important theme. Writing synopsis in English language is not an easy writing activity for English foreign students as Indonesian students. 
They always find the difficulty to share their ideas and arrange them in a comprehensive way. The students often make several errors in their writing because they do not know when to use the appropriate grammar and diction.

The definition of error analysis in relation to language errors is a technique for identifying, classifying, and systematically interpreting the errors students make in L1 learning (foreign languages) using theories and procedures that are related to the language. The primary focus of error analysis is to know how the students' effort could provide an understanding of foreign language. Conducting the analysis, the writer needs to focus on language components: morphology and syntax. Morphology is scientific study about word structure and formation rules. Morphology relates to the construction of words and parts of words. Morphology is the identification, analysis, and description, of the structure of word (word as units in the lexicon are the subject matter of lexicology). While words are generally accepted as being the smallest unit of syntax, it is clear that in most languages, word can be related to other words by rules.

According to Usha \& Kader (2016), there are some morphological errors in English language in specific areas named as affixation-related errors that referred to these terms: (1) affixation-related misuse of either prefixes or suffixes, (2) morphological errors as a result of wrong insertion word structure, (3) compound related errors is a morphological process which consists of the combination of at least two free morphemes such as a bookshop, (4). conversion-related errors are errors in the written responses of the subjects, 5). using of plural in noun phrases.

Surface strategy taxonomy highlights language errors based on the way the surface structure changes. Dulay et al (1982) classifies language errors based on Surface Strategy Taxonomy into four groups, namely (1) omission errors are caused by the absence of items that should exist in a given language unit; (2) the error of addition is an error caused by the presence of a grain or element that should not be required in a given language unit; (3) misformation is an error caused by the formation of a particular incorrect language unit construct; and (4) misordering error is caused by the placement or sorting of inappropriate elements.

Based on the problems above, the writer is interested to analyze the students' morphological errors in their writing especially in film synopsis writing. Dulay, Burt, \& Krashen (1982) stated that Error analysis is an applied linguistics approach used to identify areas of great difficulty for second language learners by applying a system of formal distinction to differentiate between the learner's first language (L1) and target language. The use of error analysis is very important in reflecting students' English learning competencies. It becomes an important instrument in first and second language learning research to improve English learning outcomes. 


\section{RESEARCH METHODOLOGY}

$\mathrm{T}$ his study is a descriptive qualitative research. In technique of analyzing the data, the researcher uses the procedure of Brown (2003) that is error identification, error classification, and errors explanation.

\section{FINDING AND DISCUSSION}

B ased on Surface Strategy Taxonomy, there are four types of errors found in writing; omission, addition, misinformation, and misordering. This strategy will be explained morphological errors in English language in specific areas as the following table:

Table 1. Morphological Errors in Omission

\begin{tabular}{|c|c|c|}
\hline Students & Morphological Errors in Omission & The Correct Morphological Form \\
\hline $\mathrm{CM}$ & $\begin{array}{l}\text { She missed the person that loves her so } \\
\text { much and she thinks she can't find } \\
\text { someone else who can treat her like } \\
\text { Gerry did to herself. }\end{array}$ & $\begin{array}{l}\text { She missed the person who loves her so } \\
\text { much. She thought that she couldn't } \\
\text { find someone else who could treat her } \\
\text { like what Gerry did to her. }\end{array}$ \\
\hline GP & $\begin{array}{l}\text { Gill then reveals his plan to escape, } \\
\text { jamming the tank's filter with a pebble. }\end{array}$ & $\begin{array}{l}\text { Gill reveals his plan to escape by } \\
\text { jamming the tank's filter with a pebble. }\end{array}$ \\
\hline AAS & $\begin{array}{l}\text { The decision makes the Carl very sad } \\
\text { because he will leave his home with his } \\
\text { beloved wife, a house full of sweet } \\
\text { memories. }\end{array}$ & $\begin{array}{l}\text { The decision makes Carl is very sad } \\
\text { because he will leave his home with his } \\
\text { beloved wife, a house full of sweet } \\
\text { memories. }\end{array}$ \\
\hline MY & Mbok Srini helpless can only cry & Mbok Srini is helpless and can only cry. \\
\hline DSC & $\begin{array}{l}\text { He meet Savannah Lynn Curtis (Amanda } \\
\text { Seyfried), a student in the spring day. }\end{array}$ & $\begin{array}{l}\text { He meets Savannah Lynn Curtis } \\
\text { (Amanda Seyfried), a student in the } \\
\text { spring day. }\end{array}$ \\
\hline YN & $\begin{array}{l}\text { Most of the movie not Old Rose telling } \\
\text { the story, but Young Rose actually living } \\
\text { the story. }\end{array}$ & $\begin{array}{l}\text { Most of the movie is not Old Rose telling } \\
\text { the story, but Young Rose is actually } \\
\text { living the story. }\end{array}$ \\
\hline NN & $\begin{array}{l}\text { Split show a young woman able to } \\
\text { combat evil because the strength she has } \\
\text { developed from personal trauma. }\end{array}$ & $\begin{array}{l}\text { Split shows a young woman able to } \\
\text { combat evil because of the strength she } \\
\text { has developed from personal trauma. }\end{array}$ \\
\hline NK & $\begin{array}{l}\text { He grew up with his father rarely with } \\
\text { him because he busy with work. }\end{array}$ & $\begin{array}{l}\text { He grew up with his father who rarely } \\
\text { accompanied him because he was busy } \\
\text { with work }\end{array}$ \\
\hline VP & $\begin{array}{l}\text { Lily desperate, not only saving Rosaleen, } \\
\text { but flee from a life she can no longer } \\
\text { endure. }\end{array}$ & $\begin{array}{l}\text { Lily is desperate, not only to save } \\
\text { Rosaleen, but to flee from a life that she } \\
\text { cannot be longer endure. }\end{array}$ \\
\hline
\end{tabular}

Omission errors in sentences are caused by the absence of language elements that should be present in the sentence. In the film synopsis written by the students found there are some errors in the omission aspect. Based on the results of morphological error analysis on the omission aspect, there is in the absence to be to glue the adjective as in Lily desperate that Lily is desperate. In addition, the absence of 'word liaison' in equivalent sentences as in Mbok Srini helpless can only cry that should be Mbok Srini is helpless and can only cry. Morphological errors at the omission level can lead to ambiguity of meaning in 
a sentence that interferes with the meaning of semantic level.

Table 2. Morphological Errors in Misinformation

\begin{tabular}{|c|c|c|}
\hline Students & Morphological Errors in Misinformation & The Correct Morphological Form \\
\hline $\mathrm{CM}$ & $\begin{array}{l}\text { And it makes Gerry have to leaving } \\
\text { Holly alone for forever. }\end{array}$ & $\begin{array}{l}\text { This condition makes Gerry has to leave } \\
\text { Holly alone forever. }\end{array}$ \\
\hline $\mathrm{CP}$ & $\begin{array}{l}\text { Darla arrives at the dentist's office and } \\
\text { almost makes Nemo die because Darla } \\
\text { is surprised by Nigel's arrival, but Gill } \\
\text { helps Nemo escape to a sewer that } \\
\text { leads to the sea. }\end{array}$ & $\begin{array}{l}\text { Darla arrives at the dentist's office but it } \\
\text { almost caused Nemo died. She is } \\
\text { surprised by Nigel's arrival, but Gill helps } \\
\text { him to escape to a sewer that leads him to } \\
\text { the sea. }\end{array}$ \\
\hline AAS & $\begin{array}{l}\text { Carl's desire to give a surprise to his } \\
\text { wife must be dashed, because Elli died } \\
\text { of illness even before his dream was } \\
\text { reached, going to the paradise falls } \\
\text { where Muntz, and coincidentally Cal } \\
\text { and Elli greatly idolized Muntz an } \\
\text { explorer. }\end{array}$ & $\begin{array}{l}\text { Carl has desire to give a surprise to his } \\
\text { wife but it must be dashed because of } \\
\text { Elli's death caused by the illness. Even } \\
\text { though, his dream hasn't reached yet. The } \\
\text { paradise falls where Muntz coincidentally } \\
\text { Cal and Elli greatly idolized Muntz as an } \\
\text { explorer. }\end{array}$ \\
\hline MY & $\begin{array}{l}\text { Every day he took care of the plant until } \\
\text { large plants and grow golden cucumber } \\
\text { fruit. Then picked the fruit and split, } \\
\text { really shocked mbok Srini when he saw } \\
\text { a baby girl in the cucumber. }\end{array}$ & $\begin{array}{l}\text { She took care of the plant until large } \\
\text { plants and grew golden cucumber fruit. } \\
\text { Then she picked the fruit and split, she } \\
\text { really shocked when she saw a baby girl } \\
\text { in the cucumber. }\end{array}$ \\
\hline DSC & $\begin{array}{l}\text { But John's father's interest make her } \\
\text { interested and make John shocked. }\end{array}$ & $\begin{array}{l}\text { But John's father makes her interested } \\
\text { and makes John shocked. }\end{array}$ \\
\hline YN & $\begin{array}{l}\text { She tell the story while on the Keldysh. } \\
\text { The men are on the Keldysh trying to } \\
\text { find a famous necklace called "The } \\
\text { Heart of the Ocean" that they think } \\
\text { sank with the ship. }\end{array}$ & $\begin{array}{l}\text { She tells the story while on the Keldysh } \\
\text { about the men who are on the Keldysh } \\
\text { trying to find a famous necklace called } \\
\text { "The Heart of the Ocean" that they think } \\
\text { sank with the ship. }\end{array}$ \\
\hline NN & $\begin{array}{l}\text { Casey abused her Uncle John since she } \\
\text { was a kid, they try to manipulate the } \\
\text { bad personalities to escape. }\end{array}$ & $\begin{array}{l}\text { Casey, who has been abused by her Uncle } \\
\text { John since she was a kid, tried to } \\
\text { manipulate the weakest personalities to } \\
\text { escape. }\end{array}$ \\
\hline NK & $\begin{array}{l}\text { In 1958, Landon called again his } \\
\text { memories by the city. Although } 40 \\
\text { years pass by, he remember still clearly } \\
\text { what happen in the past. }\end{array}$ & $\begin{array}{l}\text { In } 1958 \text {, Landon recalled his memories in } \\
\text { the city. Although } 40 \text { years have passed, } \\
\text { he can still remember clearly what } \\
\text { happened in the past. }\end{array}$ \\
\hline VP & $\begin{array}{l}\text { T-ray is more concerned with its peach } \\
\text { business, Compare to taking care Lily. }\end{array}$ & $\begin{array}{l}\text { Compared to taking care of Lily, T-ray is } \\
\text { more concerned with its peach business. }\end{array}$ \\
\hline
\end{tabular}

Constructed sentence patterns with incorrect language units can lead to incomplete information delivery. In the construction of the sentence And it makes Gerry have to leave Holly alone for forever resulting in messages to be conveyed to be confusing. The misuse of the word
'And' at the beginning of a sentence is a unit language error that causes difficulty in understanding unclear 'and' references with the equivalent sentence. In addition, 'have' as modality is not appropriate for the reference of a single third person in the sentence. The correct 
sentence is This condition makes Gerry has to leave Holly alone forever. Improper construction of sentences causes the meaning that is not in accordance with the intended purpose of the author.

Table 3. Morphological Errors in Misordering

\begin{tabular}{|c|c|c|}
\hline Students & Morphological Errors in Misordering & The Correct Morphological Form \\
\hline $\mathrm{CM}$ & $\begin{array}{l}\text { Accept Holly in any condition and } \\
\text { never leaves Holly alone. }\end{array}$ & $\begin{array}{l}\text { He accepts Holly in any condition and } \\
\text { never leaves her alone. }\end{array}$ \\
\hline $\mathrm{CP}$ & $\begin{array}{l}\text { Nemo who has the desire and want } \\
\text { to prove to his father that he is a } \\
\text { brave boy, he desperate approaching } \\
\text { a boat, and finally Nemo caught. }\end{array}$ & $\begin{array}{l}\text { Nemo has the desire to prove to his father } \\
\text { that he is a brave boy. He is desperated in } \\
\text { approaching a boat then finally Nemo is } \\
\text { caught. }\end{array}$ \\
\hline AAS & $\begin{array}{l}\text { Usually Carl wake up and run the } \\
\text { activity, and look around his house } \\
\text { has been surrounded by a Carl } \\
\text { construction workers realize that his } \\
\text { house will soon be evicted, then Carl } \\
\text { go to check mailbox. }\end{array}$ & $\begin{array}{l}\text { As usual Carl wakes up and jogging to look } \\
\text { around his house. It has been surrounded } \\
\text { by his construction workers who realized } \\
\text { that his house will soon be evicted. Then } \\
\text { he goes to check the mailbox. }\end{array}$ \\
\hline MY & $\begin{array}{l}\text { As time come the widow ask Timun } \\
\text { Mas to run to the forest her battle to } \\
\text { change her fate begins. }\end{array}$ & $\begin{array}{l}\text { At the exact time, the widow asks Timun } \\
\text { Mas to run to the forest where her battle to } \\
\text { change her fate begins. }\end{array}$ \\
\hline DSC & $\begin{array}{l}\text { John then return to the militer to be a } \\
\text { Special Forces sergeant and left with } \\
\text { his father. }\end{array}$ & $\begin{array}{l}\text { Then, John returned to the military to be a } \\
\text { Special Forces sergeant and parted with } \\
\text { his father. }\end{array}$ \\
\hline YN & $\begin{array}{l}\text { A famous diamond calling the "Heart } \\
\text { of the Ocean", he discover that the } \\
\text { does not hold the diamond, but a } \\
\text { drawing of a beautiful young woman } \\
\text { wearing it. }\end{array}$ & $\begin{array}{l}\text { A famous diamond called as the "Heart of } \\
\text { the Ocean", he discovers that the safety } \\
\text { isn't about holding the diamond, but a } \\
\text { picture of a beautiful young woman wears } \\
\text { it. }\end{array}$ \\
\hline NN & $\begin{array}{l}\text { He have } 23 \text { personalities and they } \\
\text { learn that the man have DID } \\
\text { (Dissociative Identity Disorder) with } \\
\text { several personalities. }\end{array}$ & $\begin{array}{l}\text { He has } 23 \text { personalities and soon they } \\
\text { learn that the man has DID (Dissociative } \\
\text { Identity Disorder) with several } \\
\text { personalities. }\end{array}$ \\
\hline NK & $\begin{array}{l}\text { On the night of the Drama play, } \\
\text { Landon performing as best as he can, } \\
\text { he speaking the dialogue very well. }\end{array}$ & $\begin{array}{l}\text { On the night of the Drama performance, } \\
\text { Landon performs as best as he can, he } \\
\text { speaks the dialogue very well. }\end{array}$ \\
\hline VP & $\begin{array}{l}\text { Unfortunately the memory of the } \\
\text { woman were not much left in Lily } \\
\text { mind. }\end{array}$ & $\begin{array}{l}\text { Unfortunately the memory of the woman } \\
\text { was not much left in Lily's mind. }\end{array}$ \\
\hline
\end{tabular}

The incorrect placement of language elements in sentence construction can lead to misordering errors. In the sentence, Unfortunately the memory of the woman were not much left in Lily mind; there is an incorrect grammar that is to be 'were' which refers to a single subject sentence. Incorrect use of 'were' should be 'was'. Besides 'Lily mind' refers to ownership but the phrase is not appropriate because it must be accompanied by apostrophe 's' into Lily's mind. Such grammatical errors lead to incomplete sentences. 
Table 4. Morphological errors in Addition

\begin{tabular}{|c|c|c|}
\hline Students & Morphological Errors in Addition & The Correct Morphological Form \\
\hline $\mathrm{CM}$ & $\begin{array}{l}\text { And have you ever feel how does it } \\
\text { feels if that person that you really } \\
\text { love }\end{array}$ & $\begin{array}{l}\text { Have you ever felt how was your beloved } \\
\text { man's feeling? }\end{array}$ \\
\hline $\mathrm{CP}$ & $\begin{array}{l}\text { After that, they must confront the } \\
\text { creepy fish based on the ocean, } \\
\text { then face the jellyfish forest and } \\
\text { other threats. }\end{array}$ & $\begin{array}{l}\text { After that, they must confront the creepy } \\
\text { fish inside the ocean, then face the jellyfish } \\
\text { forest and other threats. }\end{array}$ \\
\hline AAS & $\begin{array}{l}\text { And their adventure has just } \\
\text { begun. And start their adventure, } \\
\text { first they face a rain cloud and } \\
\text { lightning, which causes Carl to } \\
\text { faint. }\end{array}$ & $\begin{array}{l}\text { Their adventure has just begun. To start } \\
\text { the adventure, they face a rain cloud and } \\
\text { lightning, which causes Carl got faint. }\end{array}$ \\
\hline MY & $\begin{array}{l}\text { And buto ijo will grant Mbok Srini } \\
\text { request with a condition if the child } \\
\text { is } 17 \text { years old must be submitted to } \\
\text { him as a meal buto ijo. And mbok } \\
\text { Srini accepted the agreement. }\end{array}$ & $\begin{array}{l}\text { Then Buto ijo will request Mbok Srini to } \\
\text { submit her } 17 \text { years old child as a meal } \\
\text { buto ijo. Finally, Mbok Srini accepted the } \\
\text { agreement. }\end{array}$ \\
\hline DSC & $\begin{array}{l}\text { After two weeks, Savannah will } \\
\text { come back for college and while } \\
\text { John returns to his base. }\end{array}$ & $\begin{array}{l}\text { After two weeks, Savannah will come back } \\
\text { for college while John returns to his base. }\end{array}$ \\
\hline YN & $\begin{array}{l}\text { The members of the crew are } \\
\text { named Brock Lovett, Lewis Bodine, } \\
\text { Bobby Buell, and Anatoly } \\
\text { Mikailavich. }\end{array}$ & $\begin{array}{l}\text { The members of the crew are Brock Lovett, } \\
\text { Lewis Bodine, Bobby Buell, and Anatoly } \\
\text { Mikailavich. }\end{array}$ \\
\hline NN & $\begin{array}{l}\text { One day after having birthday } \\
\text { party in a mall, teenagers Cassey } \\
\text { Cooke, Claire Benoit and Marcia } \\
\text { are being abducted by a man with } \\
\text { a multiple personality disorder. }\end{array}$ & $\begin{array}{l}\text { One day after birthday party in a mall, } \\
\text { teenagers Cassey Cooke, Claire Benoit and } \\
\text { Marcia are abducted by a man with a } \\
\text { multiple personality disorder. }\end{array}$ \\
\hline NK & $\begin{array}{l}\text { Landon not know what to do in } \\
\text { making Jamie happy, he asked his } \\
\text { mother, but he not find the } \\
\text { answer. }\end{array}$ & $\begin{array}{l}\text { Landon didn't know what to do to make } \\
\text { Jamie happy, he had asked his mother, but } \\
\text { he did not find the answer. }\end{array}$ \\
\hline VP & $\begin{array}{l}\text { When her mother dying, she was } \\
\text { only four yo child. }\end{array}$ & $\begin{array}{l}\text { When her mother died, she was only four } \\
\text { years old. }\end{array}$ \\
\hline
\end{tabular}

The addition error is a morphological error caused by the use of language elements that are not actually needed in the sentence. The following sentence is an example of morphological mistakes on the side addition of "the members of the crew are named Brock Lovett, Lewis Bodine, Bobby Buell, and Anatoly Mikailavich." The use of the word named in the sentence is less precise because to be 'are' is sufficient to explain the sentence

\section{CONCLUSION}

T $t$ can be concluded that there is still a morphological error in the students' written film synopsis. These errors appear in omission, misinformation, misordering and addition that can lead to confusion on the 
meaning of the sentence.

\section{REFERENCES}

Brown, H. D. (2003). Language Assessment: Principles and Classroom Practices. California: San Francisco State University.

Dulay, H. C., Burt, M. K., \& Krashen, S. D. (1982). Language Two. New York: Oxford University Press.

Kennedy, X. J., Kennedy, D. M., \& Muth, M.
F. (2011). The Bedford Guide for College Writers with Reader, Research Manual, and Handbook (9th ed.). Bedford/St. Martins.

Usha, P., \& Kader, N. A. (2016). Syntactic and Morphological Error Analysis in English Language among Secondary School Students of Kerala. IOSR Journal of Humanities and Social Science (IOSR-JHSS, 21(2), 99-103. https://doi.org/10.9790/08372121991063 
English Language in Focus (ELIF), 1 (2), 81-88. https://jurnal.umj.ac.id//index.php/ELIF 